mag. Jasmina

Mirčeva

Andragoški center

Slovenije

\title{
RAZVOJ IZOBRAŽEVANJA NA PODROČJU DELA
}

\section{Kanadske izkušnje in raziskovalni pristopi}

\section{ANALIZA NEKATERIH SPODBUD ZA NOVE RAZISKOVALNE PRISTOPE IZOBRAŽEVANIA, USPOSABLIANJA IN UČENJA ZAPOSLENIH}

V znanosti ni več dvomov o tem, da so temeljne značilnosti sodobne razvite družbe, ne glede na to, kako jo imenujejo, na primer postindustrijska, postsocialistična, postkapitalistična ali informacijska, predvsem $\mathrm{v}$ proizvodnji, diseminaciji in uporabi znanja ter informacij. Med pogoji in posledicami razvoja te družbe je dialektična, dvostranska povezanost: med razvojem družbe nastaja čedalje več informa-

Svet dela je prepleten $\mathrm{z}$ informacijskimi avtocestami. cij in znanja, ti pa vse bolj generirajo in pospešujejo razvoj. V sodobni proizvodnji, družbeni reprodukciji in organizaciji se očitno zmanjšujejo delež, vloga in pomen fizičnega dela ter naravnih in tehnolo-

ških dejavnikov, povečuje pa se vloga znanja in informacij. Po mnenju Betchermanna, Mc Mullena in Davidmana (6-36: 1998) so spremembe in gibanje postindustrijskega trga dela večinoma posledica:

- spremenjene strukture zaposlovanja (naraščanje deleža informacijskih storitev na račun zmanjševanja tradicionalne proizvodnje dobrin in storitev, uvajanje računalniške tehnologije, spreminjanje življenjskega sloga in ritma idr.);

- novih participacijskih vzorcev (naraščanje deleža ženske delovne sile v strukturi za- poslenih, spreminjajoče se sodelovanje mladih pri delu in naraščanje deleža starejših zaposlenih);

- spreminjanja pogodb o zaposlovanju;

- legalizacije statusa nekaterih nestandardnih oblik zaposlovanja in dela.

Naštete značilnosti trga dela in zahteve zaposlovanja narekujejo ter objektivno spodbujajo povpraševanje po visoko izobraženi, usposobljeni in informirani delovni sili. Zato je tudi znani kanadski futurolog in sociolog Marshall Mc Luhan (1995) poudaril, da je svet že postal globalna vas, ki jo križajo informacijske avtoceste, da si je znanje zagotovilo prevladujočo vlogo, celotna družba pa počasi pridobiva značilnosti »učeče se družbe«.

\section{ZNAČILNOSTI KANADSKE DRUŽBE IN IZ TEGA IZHAJAJOČIH RAZISKOVALNIH IZZIVOV}

Izhajajoč iz takih zahtev trga dela in gospodarskega napredka $v$ sodobnih razvitih družbah, so se v Kanadi odločili za dve zanimivi raziskavi: Razvoj spretnosti na delovnem mestu - usposabljanje za novo ekonomijo in Strategija za uspeh: profil razvijajočih se malih in srednje velikih podjetij. Raziskavi sta izpeljali raziskovalni skupini G. Betchermanna, N. Leckieja in K. McMullena leta 1997 in J. Baldwina, W. Chandlerja, C. Lea in T. Papalliadisa leta 1994. Širši cilj obeh skupin pa je bil preučevanje stanja izobraževanja zaposlenih $\mathrm{v}$ gospodarstvu in dosega- 
Kanada je velika, tržno usmerjena in razvita država. Število prebivalcev je bilo leta 1997 29,3 milijona, bruto družbeni proizvod na prebivalca je bil 19.248 USD, delež investicij v bruto družbenem proizvodu pa 19 odstotkov. Število vseh zaposlenih je bilo 13.506 , število zaposlenih $v$ industriji 3.099 in število zaposlenih v kmetijstvu 554 ; stopnja brezposelnosti je bila 9,5 odstotka. V strukturi kanadskega gospodarstva se srečujejo velika, srednje in mala, nacionalna in tudi mednarodna podjetja. Po P. Philipsu (1998) si 200 od vseh podjetij v Kanadi lasti nekaj manj kot polovico gospodarskega dobička, 200.000 malih in srednje velikih podjetij pa drugo polovico. Pri ustvarjanju bruto družbenega proizvoda je delež kmetijstva razmeroma nizek in znaša le 3 odstotke, proizvodnja in gradbeništvo imata 25-odstotni delež v celotnem bruto družbenem proizvodu, prevladuje pa delež storitev.

nje večjih izobraževalnih ter učnih učinkov na tem področju. Na njun raziskovalni pristop in vsebino preučevanja so nedvomno vplivali različni dejavniki: velikost države, njena zgodovina, geografski položaj, družbeni red, gospodarski razvoj in tudi tradicija, družbena struktura, kulturni vzorci, sistem izobraževanja in učenja ter navsezadnje tudi področje dela. Ta struktura gotovo posredno ali neposredno vpliva na potrebe po ustrezni izobraženosti, usposobljenosti in spretnosti vseh zaposlenih

Kanadska podjetja so predvsem v zasebni lasti, imajo razvito tehnologijo, so dokaj fleksibilna in praviloma precej spodbujajo vlaganja $\mathrm{v} »$ job training «, nekatere analize pa so tudi pokazale, da so zelo motivirana za razvoj formalnih in tudi manj formalnih ter standardiziranih oblik učenja zaposlenih. Ravno ta na učenju utemeljeni razvoj, ki je obenem usmerjen inovativno, fleksibilen in upošteva različne oblike ter načine učenja, odpira možnosti in spodbuja nove analize ter raziskovalne pristope.

\section{ZAKAJ SO KANADSKE IZKUŠNJE ZANIMIVE ZA SLOVENIJO?}

V osnovi so kanadske izkušnje in praksa drugačne v primerjavi s slovenskimi. Kanada je velika država $\mathrm{z}$ razvito tržno ekonomijo, $\mathrm{z}$ visoko stopnjo rasti, je izvozno usmerjena, ima pa tudi izrazito visok bruto družbeni proizvod, ki je nedvomno med najvišjimi na svetu. Skupaj z Združenimi državami, Švico, Švedsko in Japonsko spada tudi med najbogatejše države na svetu.

Slovenija ima povsem drugačne možnosti. Po velikosti svojega ozemlja in številu prebivalstva pripada skupini manjših držav, njeni naravni in materialni viri so razmeroma omejeni, zasebno in tržno usmerjeno gospodarstvo pa je bolj značilnost gospodarskega razvoja v zadnjem desetletju. Kljub temu je Slovenija v okviru svoje referenčne skupine (vzhodno- in srednjeevropskih držav) država $\mathrm{v}$ tranziciji $\mathrm{z}$ razmeroma visoko rastjo in čedalje intenzivnejšim razvojem. Glede temeljnih gospodarskih in razvojnih kazalcev (bruto družbeni proizvod, izvoz, gospodarska rast, zaposlenost, rezerve tujih valut ipd.) je Slovenija nedvomno med vodilnimi državami tranzicije. Ne bistveno drugačne od tega so še stopnja izobraženosti in usposobljenosti, pa tudi splošna raven znanja in spretnosti zaposlenih, ki je pomembna za doseganje ustrezne kakovosti dela, inovativnosti, napredovanja podjetij in zmanjševanje stopnje brezposelnosti v družbi. To pa so dejavniki, ki so za nadaljnji razvoj obeh držav izjemno pomembni.

To izhodišče je bilo in je še vedno izziv za številne znanstvenike. Cilj znanstvenih in razi- 
skovalnih projektov je bil usmerjen predvsem $\mathrm{k}$ zagotavljanju koristnih podatkov za razumevanje različnih vidikov izobraževanja, usposabljanja in učenja $v$ gospodarstvu. Mednarodne izkušnje ter preučevanje in analiziranje raziskovalnih pristopov, ki so v domačem prostoru še vedno neznani, so gotovo izredno pomembni pri koncipiranju lastnih raziskav. Zato je tudi namen tega prispevka predstaviti dve kanadski raziskavi, ki sta bili izpeljani v zadnjem desetletju. Obenem pa te raziskovalne izkušnje odpirajo nekatera nova konceptualna in metodološka vprašanja in s tem tudi spodbujajo nove raziskave, poglede, ideje in tudi ambicioznejše in globlje teoretične ali praktične koncepte izobraževanja, usposabljanja in učenja v skladu s potrebami dela ter sodobne družbe.

\section{RAZVOJ SPRETNOSTI NA DELOVNEM MESTU - USPOSABLJANIE ZA NOVO EKONOMIJO}

Raziskovalni projekt Razvoj spretnosti na delovnem mestu v Kanadi - usposabljanje za novo ekonomijo (Developing Skills in the Canadian Workplace - Training for the New Economy (G. Betcherman, N. Leckie, K. McMullen, 1997)) je obravnaval pogoje, spremembe in usmeritve kanadskega gospo-

Človeški kapital je še vedno edini vir za doseganje nove vrednosti. darstva in družbe $\mathrm{v}$ zadnjih dveh desetletjih. Po mnenju avtorjev se je razvoj kanadske države usmerjal predvsem $\mathrm{k}$ pridobivanju novih trgov in odprtim gospodarstvom, $\mathrm{k}$ uvajanju razvite tehnologije, storitvam in informacijsko zastavljenim dejavnostim. Hkrati so razvoj zaznamovali tudi razmeroma visoka stopnja brezposelnosti, upadanje razvoja proizvodnje in obstoj razmeroma nestabilnega trga dela. Ti procesi in značilnosti kanadske družbe so zahtevali ponovno preverjanje vloge in strategij delovanja organizacij, ki naj bi bile usmer- jene $\mathrm{k}$ večji produktivnosti in uspehom, spreminjanju vzorcev obnašanja posameznikov in tudi k oblikovanju strategije za izboljševanje statusa in položaja posameznika $v$ družbi in pri delu. Temeljni pogoj za doseganje teh organizacijskih ciljev in ciljev posameznikov so po mnenju avtorjev izboljševanje tako imenovanega nevidnega kapitala (invisible capital) oziroma temeljitejša izraba človeškega kapitala, pridobivanje novega znanja in spretnosti zaposlenih.

Raziskava je bila zastavljena na predpostavki, da analiza eksternih dejavnikov (število institucij, ki organizirajo različne oblike izobraževanja in usposabljanja, število zaposlenih, ki sodelujejo v izobraževalnih procesih, preučevanje prevladujočih programov usposabljanja ipd.) ne zadošča za bolj poglobljeno obvladovanje te problematike. Zato je bil tudi osnovni cilj raziskave usmerjen $\mathrm{k}$ internim učnim predpostavkam, potrebam in značilnostim podjetij, ki določajo vsebine, oblike in metode izobraževanja, $\mathrm{k}$ njegovim izidom ter dejavnikom, ki lahko izboljšajo kakovost in učinke. Z drugimi besedami, raziskava je bila usmerjena $\mathrm{k}$ preučevanju pojavnih oblik in učinkov učenja $v$ podjetjih, njeni izidi pa so bili nedvomno dragoceni tudi pri načrtovanju gospodarske in izobraževalne politike, usmerjanju prakse v prihodnosti ter koordiniranju sprememb.

Za doseganje raziskovalnih ciljev in za verifikacijo raziskovalnih hipotez so $\mathrm{v}$ projektu uporabili dokaj široko in zahtevno metodologijo ter postopke, ki so zagotovili pridobivanje kvantitativnih in kvalitativnih podatkov. $\mathrm{V}$ raziskavo so bili vključeni zaposleni in tudi delodajalci iz izbranega vzorca gospodarskih subjektov. Hkrati je bila izvedena longitudinalna analiza, ki je omogočila raziskovanje načinov učenja in razvijanja spretnosti na delovnem mestu v različnih časovnih obdobjih. Vsebina vprašalnikov je zagotovila podatke o »first generation issues« oziroma informacije 
o izidih prve tematske generacije (vidnejši vidiki izobraževanja in usposabljanja zaposlenih) in podatke o "second generation issues « oziroma o izidih druge tematske generacije (globlji in manj vidni dejavniki, ki usmerjajo izobraževanje, usposabljanje in njegove posledice). Cilj empiričnega dela raziskave je bil odgovoriti na vprašanja, ki obravnavajo značilnosti izobraževanja in usposabljanja (kakšni so drugi učinki učenja, pomen, količina, tipi, intenziteta, trajanje izobraževanja, učne smernice in kakšna so prizadevanja zaposlenih in delodajalcev, ki organizirajo izobraževanje $\mathrm{v}$ teh podjetjih) ter odločitve za usposabljanje (zakaj zaposleni in delodajalci podpirajo vlaganje $\mathrm{v}$ izobraževanje in usposabljanje ali mu nasprotujejo, kako se uresničujejo odločitve o izobraževanju in usposabljanju, katere so ovire in motivacija za usposabljanje, kakšna je vloga zaposlenih, delodajalcev in države pri spodbujanju dejavnosti usposabljanja). Izidi raziskave pa so bili usmerjeni $\mathrm{k}$ zagotavljanju ustreznih podatkov o tem, kako naj bi se oblikovala optimalna izobraževalna in učna strategija, ki bi upoštevala interese zaposlenih in tudi delodajalcev, kako naj bi vlaganja $\mathrm{v}$ izobraževanje pripomogla $\mathrm{k}$ boljšim delovnim rezultatom, kako bi se lahko z izobraževanjem izboljšal status posameznika pri delu in v družbi na splošno. To preučevanje je namenilo precej pozornosti tudi ugotavljanju učnih potreb zaposlenih, značilnostim organizacijske kulture in klime.

Prvi del raziskave je potekal kot telefonsko in poštno anketiranje in je bil izveden leta 1993 in 1995. Longitudinalni pristop je omogočil razlago vprašanj, na katera ne bi mogli odgovoriti le $\mathrm{v}$ enem časovnem obdobju. Telefonsko anketiranje je vključilo vzorec 2.584 respondentov ter posameznikov, ki so bili zaposleni ali so sodelovali s podjetji, in tudi tistih, ki so bili zaposleni v administraciji, organizacijah, ki ponujajo izobraževalne storitve, in kmetijstvu. V sklopu te populacije so upora- bili naslednja merila in diversifikacijo podjetij: industrijska podjetja, industrija pa je bila razdeljena $\mathrm{v}$ deset podskupin, velikost podjetij, ki so jo sestavljale tri podskupine, in regionalna distribucija podjetij, zastopana $\mathrm{z}$ desetimi regijami. Anketni vprašalnik je vseboval predvsem vprašanja z možnostjo izbire enega ali več odgovorov, predvsem zaprtega tipa, bilo pa je tudi nekaj odprtih vprašanj. Končni odziv telefonske ankete $\mathrm{v}$ obeh časovnih obdobjih je bil 43,2 odstotka vključenega vzorca, odziv na poštno anketiranje pa je bil 33,7odstoten.

$Z$ raziskavo so dokazali, da so učinki usposabljanja večji v velikih podjetjih in $\mathrm{v}$ podjetjih $\mathrm{z}$ zelo razvito tehnologijo ter inovativno organizacijsko kulturo. Rezultati raziskave so tudi pokazali, da je večina celotnega usposabljanja v izbranih podjetjih potekala kot neformalno učenje, formalni načini posredovanja znanja in spretnosti pa so se razvijali predvsem $v$ zadnjih letih. Formalno učenje, ki izraža predvsem skupne načine pridobivanja znanja in spretnosti, je prevladovalo predvsem med zaposlenimi z managerskimi, profesionalnimi in tehničnimi poklici. Raziskava je ravno tako pokazala, da je obseg izobraževanja in usposabljanja odvisen od velikosti podjetja, saj so večja podjetja v izobraževalne dejavnosti vlagala veliko več sredstev kot manjša.

$\mathrm{V}$ drugem delu raziskave je bila uporabljena metoda preučevanja primerov, ki je zagotovila natančnejše informacije o sestavi podjetij ter internem izobraževanju in usposabljanju. Za metodo preučevanja primerov je bilo izbranih 18 podjetij različne velikosti, regionalne distribucije in panožne pripadnosti. Preučevanje primerov je potekalo na podlagi metod opazovanja in intervjuvanja. Temeljni cilj metode preučevanja primerov je bil usmerjen $\mathrm{k}$ ugotavljanju organizacijske strukture, odločitvam o usposabljanju in analiziranju vpliva usposabljanja na delovanje podjetij ter zaposlenih. Večino podatkov v drugi fazi so dali management za razvoj človeških virov ali vodilni, ki so bili odgovorni za organizacijo izobraževalne dejavnosti, sindikalni predstavni- 


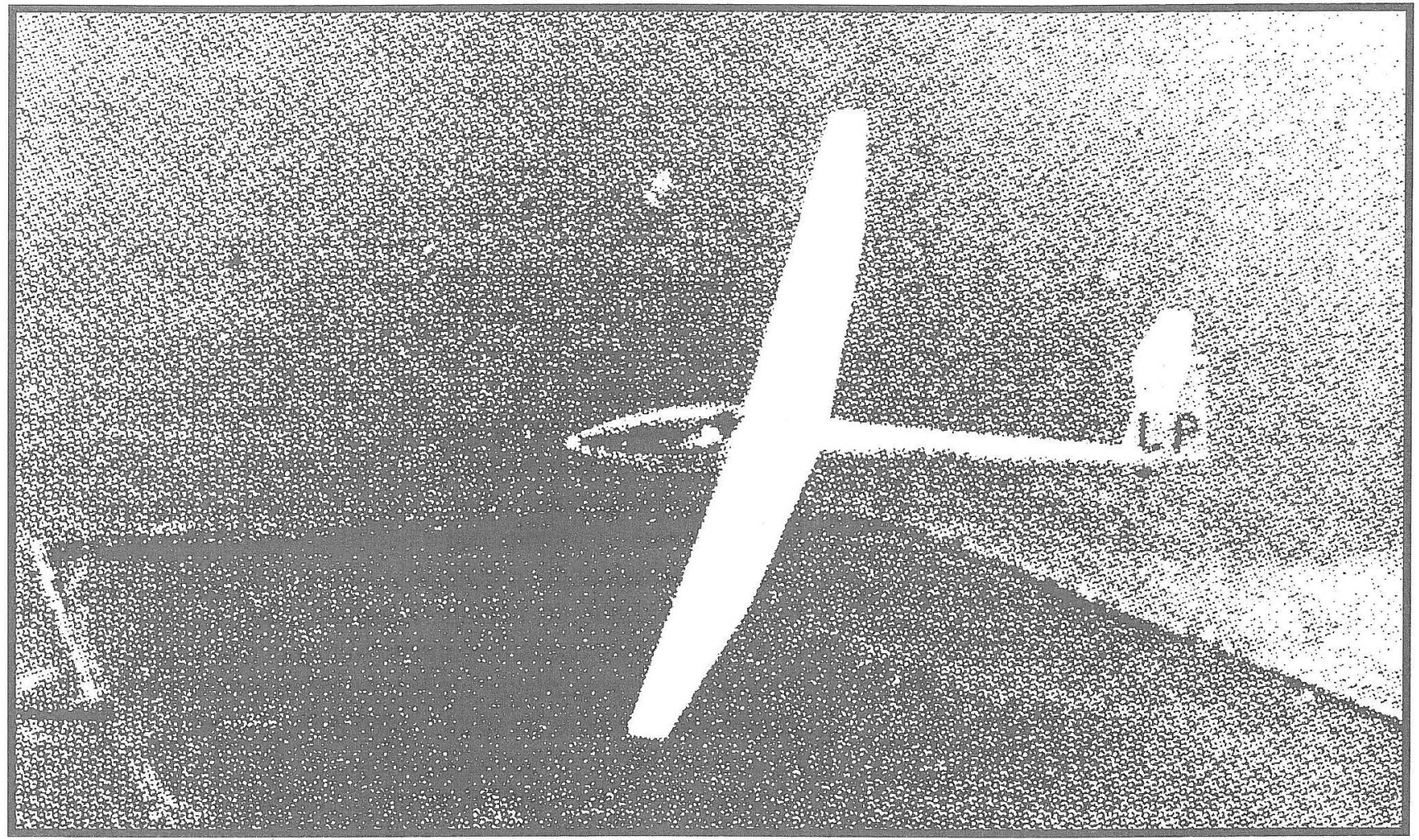

$\mathrm{ki}$, svetovalci in zaposleni na oddelkih, kjer je potekalo usposabljanje. Zadnja faza preučevanja primera je bila priprava poročila.

Čeprav z metodo preučevanja primera ni bil zagotovljen reprezentativni vzorec - vključenost deležev iz celotne strukture zaposlenih, upoštevaje spolno, starostno, izobraževalno in poklicno distribucijo, so dobili nekatere zelo pomembne informacije. $S$ to metodo je bila namreč realizirana ne le možnost za pridobivanje podatkov o izobraževanju in usposabljanju zaposlenih, temveč so raziskovalci prišli do bolj poglobljenih ugotovitev, ki so segale tudi na področje managementa človeških virov, na mikro ravni, $v$ sklopu podjetij in tudi na makro ravni oziroma $v$ celotnem gospodarstvu. Na podlagi širše analize izobraževalnih dejavnosti so bile identificirane tri vrste podjetij: podjetja, $v$ katerih so izobraževalne in učne dejavnosti predvsem neformalne in nenamerne (naključne); podjetja, $v$ katerih se formalno izobraževanje in usposabljanje organizirata pri sprejemanju novih delovnih nalog ali uvajanju sodobnejše tehnologije, izobraževanje je $\mathrm{v}$ teh primerih časovno omejeno; podjetja, ki se označujejo kot »učeče se organizacije«, v katerih je učenje postalo integralni del celotnega delovnega procesa. Tudi ekonomske analize, izvedene $\mathrm{v}$ raziskavi, so pokazale, da obstaja velika korelacija med usposabljanjem, višino plač, ekonomsko udeležbo, fleksibilnostjo do nove tehnologije in razvojem človeških virov. $\mathrm{V}$ raziskavi so bile tudi navedene nekatere izobraževalne ovire, ki so jih $\mathrm{v}$ preučevanih podjetjih povzročili predvsem dokaj tradicionalna in rigidna poslovna strategija ter neustrezna managerska stališča.

Na podlagi splošnih ugotovitev je bil v okviru projekta narejen poskus za oblikovanje vsestranskega modela izobraževanja in učenja zaposlenih, ki naj bi upošteval temeljne organizacijske značilnosti (na primer nova tehno- 
logija, organizacijska kultura in klima, organizacijska struktura in strategija). Rezultati so indicirali, da usmeritve izobraževanja in usposabljanja niso odvisne le od ciljev podjetja, temveč tudi odločitev in zanimanja posameznikov. Dragocene so bile tudi ugotovitve, ki so pokazale, da obstajajo heterogeni učni pristopi in oblike pridobivanja znanja ter spretnosti in da podjetja po svoje sodelujejo pri izvedbi formalnega izobraževanja ter pri neformalnem pridobivanju znanja. Na voljo je bila tudi uporabna klasifikacija učenja $v$ različnih podjetjih. Raziskava je tudi opozorila na pomanjkanje izobraževalnih možnosti in manjšo participacijo dveh tipov podjetij, in sicer malih in srednje velikih podjetij, pri izobraževanju pa le redko sodelujejo tudi posamezniki na dnu poklicne hierarhične lestvice.

$\mathrm{V}$ skladu $\mathrm{z}$ ugotovitvami raziskave mala podjetja nimajo vedno možnosti, da bi zagotovila sredstva za izobraževanje, so slabše informirana o možnostih za usposabljanje, ravno tako pa si tudi težje privoščijo pomanjkanje ključnih ljudi med izobraževanjem. Kot rešitev je bilo v raziskavi predlagano oblikovanje mreže institucij, ki naj bi zagotovila posebne učne možnosti zaposlenim in tudi posebne časovne ter druge ugodnosti, namenjene malim podjetjem. Spodbujala bi tudi večje sodelovanje malih in srednje velikih podjetij pri organiziranju in izpeljavi izobraževalne dejavnosti. Posebna pozornost naj bi bila namenjena tudi posameznikom brez prihrankov, ki pogosto niso motivirani za sodelovanje $\mathrm{v}$ izobraževalnem procesu, in tistim, ki niso ustrezno informirani.

Čeprav je bila metodologija raziskovanja usmerjena predvsem $\mathrm{k}$ evalvaciji izobraževanja/usposabljanja na makro ravni, je vsekakor dala širši vpogled v možnosti na tem področju. Projekt je poudaril nujnost državnega poseganja in pomoči, potrebo po nadaljnji obravnavi tega pojava, empirična analiza pa je še posebej opozorila na razmerje med po- slovnim uspehom in usposabljanjem, hkrati pa tudi nujnost oblikovanja ustrezne managerske strategije in nekatere neformalne alternativne oblike usposabljanja ter pomembnost razvoja informacijskega sistema.

\section{STRATEGIJA ZA USPEH: PROFIL RAZVIJAJOČIH SE MALIH IN SREDNJE VELIKIH PODJETIJ}

Pri preučevanju razvoja in doseganja uspešnosti podjetij v sodobnem kanadskem gospodarstvu so se v raziskavi Strategija za uspeh: profil razvijajočih se malih in srednje velikih podjetij (Strategies for Success - A Profile of Growing Small and Medium-sized Enterprises in Canada) avtorji (J. Baldwin, W. Chandler, C. Lea, T. Papalliadis, 1994) osredotočili na specifično skupino podjetij. Gre namreč za skupino uspešnih malih in srednje velikih podjetij ter preučevanje dejavnikov, ki bi omogočili njihov razvoj in uspeh. Temeljni cilj raziskave je bil predvsem $\mathrm{z}$ analizo njihove povezanosti s strategijo in vzorci delovanja izobraževanja, usposabljanja zaposlenih ugotoviti lastnosti izbranih uspešnih podjetij in tudi poudariti različnost pristopov pri oblikovanju take strategije ter dejavnosti med bolj in manj uspešnimi podjetji.

Pri tem je bil prvi korak izbira

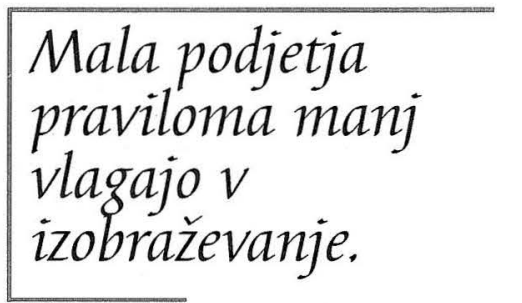
vzorca malih in srednje velikih podjetij, ki so bila le redko predmet socioloških, ekonomskih in izobraževalnih analiz, najbrž zaradi njihove heterogenosti, fleksibilnosti, neunificiranosti ter uporabe manj konvencionalnih in težje merljivih načinov za posredovanje znanja, spretnosti ter prenašanja informacij. Kljub njihovi manjši uveljavljenosti ta tip podjetij nima obrobne ali zanemarljive vloge $\mathrm{v}$ gospodarstvu in družbi. Njihov delež v celotni strukturi kanadskih podjetij je približno 60 -odstoten, se opazno razvijajo, kljub temu pa so hkrati tudi zelo ranljiva in odvisna od poslovnega okolja. 
K tem značilnostim so avtorji raziskave dodali še nekatere njihove skupne lastnosti, kot so velika fleksibilnost in hitro reagiranje na potrebe kupcev, dobra kakovost njihovih proizvodov in storitev, kakovostna managerska strategija, uspešni marketing ter zelo izobražena in usposobljena delovna sila. $Z$ vidika izobraževanja in usposabljanja je ravno tako očitno, da imajo mnoga od teh podjetij ekstenzivni program usposabljanja, posebno politiko in pristope do učenja zaposlenih, še posebej glede utilizacije znanja, reševanja organizacijskih in managerskih problemov ter uporabe človeškega kapitala.

Temeljna hipoteza raziskave je bila, da obstaja povezanost med strukturnimi in drugimi značilnostmi malih in srednje velikih podjetij ter njihovim poslovnim uspehom. Temu ustrezna je tudi domneva, da obstaja med malimi in srednje velikimi podjetji specifična kombinacija lastnosti, strategij, managerskih vzorcev in dejavnosti, ki se razlikuje od kombinacije teh dejavnikov v velikih podjetjih. $V$ raziskavi je bila uspešnost podjetij definirana kot poslovni in dobičkonosni rezultat, ki temelji na hitrem razvoju, uspešnosti, ustreznem okolju in možnostih delovanja, neposredno povezanih z visoko stopnjo produktivnosti in razvojem človeških virov.

$\mathrm{V}$ raziskavi so bili uporabljeni predvsem instrumenti, metode in načini za zbiranje kvantitativnih podatkov. Osnovni način pridobivanja teh podatkov je bil anketiranje. Anketni vprašalnik je vseboval različne vidike izobraževalnih usmeritev, vključujoč tudi strategije tehnološkega razvoja, razvoj človeških virov in financiranje $\mathrm{v}$ sklopu širšega mnagementa, marketinga in uporabe proizvodne tehnologije. Ta metodološki instrumentarij je zagotovil tri skupine odgovorov oziroma podatke o značilnostih podjetij, in sicer podatke o prostorski razpršenosti, lastništvu in sodelovanju z drugimi podjetji; podatke o operacijskih, organizacijskih in finančnih dejavnostih podjetij ter podatke o dejavnikih, ki so pomembni za razvoj podjetja in zagotovitev kakovostnega delovanja.
Vprašalnik je imel 13 vprašanj z možnostjo izbire enega ali več odgovorov. Čeprav je bil anketni vprašalnik namenjen posameznikom (zaposlenim in delodajalcem) $\mathrm{v}$ izbranih podjetjih, ni zagotovil podatkov o anketiranih, temveč predvsem objektivne podatke o podjetjih. To pomeni, da so bila osnovni vzorec preučevanja podjetja.

Kot je bilo že prej poudarjeno, je bil raziskovalni vzorec sestavljen iz malih in srednje velikih podjetij, ki imajo po kanadskih merilih manj kot 500 zaposlenih in manj kot 100 milijonov kanadskih dolarjev dobička na leto. Zajel je podjetja, ki so v obdobju štirih let (od 1984 do 1988) imela precejšen porast v zaposlovanju, prodaji in dobičku in so dosegla tudi večjo produktivnost, višino plač zaposlenih, tržni delež in boljše izvozne usmeritve od povprečja.

Na podlagi baz podatkov Longitudinal Employment and Payroll in Incorporate Business File je bilo izbranih 2.157 podjetij. Ta vzorec je bil nato razdeljen $\mathrm{v}$ petih kanadskih regijah in desetih industrijskih panogah. Stopnja responzivnosti na vprašalnike je bila 1.480 ali 68,6 odstotka celotnega vzorca. V skladu s temeljnim ciljem raziskovalnega prizadevanja, ki je bil še posebej usmerjen k pomembnosti nekaterih strategij in dejavnosti, je bilo ugotovljeno, da nekatere na novo pridobljene lastnosti vplivajo na odličnost podjetij. Kljub temu se je pokazalo, da notranje dejavnosti in prizadevanja malih ter srednje velikih podjetij niso zadosten dejavnik za razvoj in doseganje inovativnosti. Zato so bili v raziskavi preučevani tudi eksterni dejavniki, kot so vstop na nove trge, uvajanje novih proizvodov, razvoj nove tehnologije in zadovoljevanje ekoloških standardov.

$\mathrm{V}$ skladu z drugim ciljem, razlikovanje med bolj in manj uspešnimi podjetniškimi strategijami ter dejavnostmi, je raziskava poudarila, da obstajajo določene lastnosti, ki so nujno potrebne za preživetje in uspešno delovanje malih ter srednje velikih podjetij, kot so 
Raziskava ni potrdila predpostavke, da sta izobraževanje in usposabljanja prevladujoča dejavnika, ki ločujeta uspešnejša podjetja od manj uspešnih. Očitno je bilo, da izobraževanje in usposabljanje ne moreta biti sama po sebi zadosten dejavnik, ki lahko samostojno pripomore $\mathrm{k}$ uspešnosti malih in srednje velikih podjetij, vendar sta gotovo med najpomembnejšimi ter pogoj za uresničevanje in doseganje organizacijskih ciljev.

dobra managerska strategija, razvoj človeških virov, ustrezno financiranje izobraževalne dejavnosti ipd. Kljub temu so bile temeljne značilnosti, ki ločujejo uspešna podjetja od neuspešnih podjetij, po mnenju avtorjev raziskovalna in razvojna dejavnost, dostop do novih in še posebej tujih trgov, pogostejše uvajanje sodobnih proizvodnih programov in zmožnost obvladovanja razvite tehnologije.

Pri preučevanju temeljnih dejavnikov za razvoj in doseganje večje uspešnosti malih in srednje velikih podjetij so bile zanimive tudi nekatere druge ugotovitve. Med njimi je tudi ugotovitev, da uspešnost podjetij ni preveč odvisna od vladne politike, temveč bolj od notranjih dejavnikov podjetij. Sodelovanje in vpliv vlade pa sta precej pomembna pri delovanju nekoliko manj uspešnih podjetij. Z raziskavo so ravno tako ugotovili, da je panožna pripadnost podjetij precej pomemben dejavnik usmerjanja ter da imajo glede panožne distribucije mala in srednje velika podjetja tudi specifične razvojne strategije.

Lahko sklepamo, da je omenjena raziskava ugotovila nekatere pomembne značilnosti malih in srednje velikih podjetij in da je pripomogla k identifikaciji dejavnikov, ki ločujejo uspešnejša podjetja od manj uspešnih malih in srednje velikih podjetij. Inovativna strategija in dejavnosti so najpomembnejše pri ločevanju uspešnejših podjetij od manj uspešnih. $\mathrm{V}$ tem pogledu je omenjena raziskava gotovo spodbuda in izziv za nadaljnje preučevanje inovativnosti, v okviru specifične skupine podjetij in tudi širše $v$ gospodarstvu ter sodobni družbi na splošno.

\section{SKLEPNE MISLI}

Vpogled v literaturo in raziskovalne vire o razvoju izobraževanja na področju dela priča o naraščajočem zanimanju znanosti za doseganje večje fleksibilnosti, inovativnosti in učinkovitosti na delovnem mestu, kar je nedvomno $\mathrm{v}$ skladu z zahtevami tako imenovane nove ekonomije. Tudi omenjeni raziskavi opozarjata na pomembnost preučevane problematike $\mathrm{v}$ celotni kanadski družbi, ki se mora kljub nenehnemu razvoju prilagajati nekaterim hitrim spremembam in usmeritvam in tudi podpirati strategije za doseganje večje uspešnosti pri naraščajoči skupini malih in srednje velikih podjetij. Poudarek prispevka ni toliko na končnih ugotovitvah, temveč bolj na raziskovalni metodologiji, pristopih in sodobnih znanstvenih prizadevanjih pri preučevanju te problematike v eni od vodilnih držav glede izobraževanja in učenja v podjetjih. Tak pristop, upoštevaje podobnosti in različnost okolja, pa je lahko izziv in spodbuda za nadaljnje nacionalne in primerjalne analize ter sodelovanje.

\section{LITERATURA IN VIRI}

Betcherman, G., Davidman, K., McMullen, K., 1998. Training for the New Economy. Renouf Publishing Co., Ottawa.

Betcherman, G., Leckie, N., McMullen, K., 1997. Developing Skills in the Canadian Workplace. The Results of the Ekos Workplace Training Survey. Renouf Publishing Co., Ottawa.

Baldwin, J., 1994. Strategies for Success - A Profile of Growing Small and Medium-sized Enterprises in Canada. Statistics Canada, Ottawa.

Ferfila, B. and Philips, P., 1998. Slovenia and Canada. A Comparative Approach, FDV, Ljubljana.

MacLuhan, M., 1995: The Global Village Transformations in World Life and Media in the $21^{\text {st }}$ Century. Oxford University Press, Oxford. 